University of Nebraska - Lincoln

DigitalCommons@University of Nebraska - Lincoln

\title{
The Double-Edged Sword of Biological Control in Conservation and Restoration
}

Svata M. Louda

University of Nebraska - Lincoln, slouda1@unl.edu

Peter Stiling

University of South Florida, pstiling@chuma1.cas.usf.edu

Follow this and additional works at: https://digitalcommons.unl.edu/bioscilouda

Part of the Ecology and Evolutionary Biology Commons

Louda, Svata M. and Stiling, Peter, "The Double-Edged Sword of Biological Control in Conservation and Restoration" (2004). Svata M. Louda Publications. 19.

https://digitalcommons.unl.edu/bioscilouda/19

This Article is brought to you for free and open access by the Papers in the Biological Sciences at DigitalCommons@University of Nebraska - Lincoln. It has been accepted for inclusion in Svata M. Louda Publications by an authorized administrator of DigitalCommons@University of Nebraska - Lincoln. 
Published in Conservation Biology 18:1 (2004), pp. 50-53; doi: 10.1111/j.1523-1739.2004.00070.x Copyright @ 2004 Society for Conservation Biology; published by Wiley-Blackwell. Used by permission. http://www.wiley.com/bw/journal.asp?ref=0888-8892

Submitted February 18, 2003; revised and accepted May 18, 2003; published online January 30, 2004.

\title{
The Double-Edged Sword of Biological Control in Conservation and Restoration
}

\author{
Svata M. Louda \\ School of Biological Sciences, University of Nebraska-Lincoln, Lincoln, NE 68588-0118, USA; email slouda@unl.edu \\ Peter Stiling \\ Department of Biology, University of South Florida, Tampa, FL 33620, USA
}

\section{Introduction}

The most fundamental question in considering deliberate introductions of exotic species against invasive species is whether the outcomes can be predicted precisely enough a priori to know with some certainty that the benefits will outweigh the environmental costs. This issue is obscured by reiteration of an overly simplistic description of the ecology underlying biological control. Classical biological control is not a simple exercise in "community re-assemblage" (Hoddle 2004[this issue]); it involves the introduction of alien organisms into new species assemblages, in new physical environments, and without the rest of their foodweb. Predicting the outcome of such introductions is infinitely more complex than implied by the idea of "reestablishing natural enemies" of an invasive species. Direct ecological interactions are difficult enough to predict, but indirect interactions - those mediated through a third species or foodwebs-are even harder to predict (Strauss 1991; Paine 1992; Wooton 1994; Menge 1997). In suggesting that biocontrol efforts are "restoring balance" by "using exotic species to control invasive exotic species," Hoddle (2004 [this issue]) skirts the essential ecological issue: predicting the magnitude of the outcome of the full set of new interactions in a new environment.

Our aim is to review more, highly relevant evidence and to outline an alternative, ecological perspective on the use of "exotics to control invasive exotics" (Hoddle 2004). We summarize data on nontarget effects that were ignored or that challenge Hoddle's interpretations and then briefly address the points he raised on classical biological control. This synopsis highlights important reasons for increased caution and continuing development of improved ecological risk assessment, especially for conservation and restoration. In these contexts in particular, we think that the overarch- ing guideline, as in medicine, should be, first, do no harm (Simberloff \& Stiling 1996).

\section{More Evidence on Nontarget Effects}

Recent quantitative studies show unexpected levels of nontarget feeding and impact by some biological control insects (Howarth 1991; Follett \& Duan 2000; Wajnberg et al. 2001). Several studies not cited, or dismissed, by Hoddle provide additional strong, quantitative evidence that biological control efforts can have more far reaching and complicated outcomes than expected. To predict the interaction outcomes observed, adequate risk assessment prior to release would have required more ecological data to supplement the behavioral and physiological data from host-specificity tests (Louda 1999; Louda et al. 2003a; 2003b).

Johnson and Stiling (1996) reported significant feeding by the moth Cactoblastis cactorum on native cacti in southern Florida, which is within hitch-hiking or islandhopping distance of the Caribbean islands onto which the moth was introduced as a biocontrol agent (Stiling 2002). In Florida the moth now threatens the already endangered native $O$. corallicola with extinction (Stiling et al. 2000). This moth is a specialist on the genus Opuntia, so the case highlights the fact that narrow host specificity per se does not guarantee safety (Louda et al. 2003b). The case also suggests the need to expand quantitative assessments of potential ecological risks to adjacent regions within potential dispersal distance.

Louda and colleagues $(1997 ; 1998)$ reported that Rhinocyllus conicus, a thistle specialist introduced to control exotic species, is both widespread and reducing seed production by multiple native thistles in nature reserves and three national parks in the central United States. Prior data (Louda \& Potvin 1995) make it clear that the 
further decreases in seed production threaten populations of Cirsium canescens in its habitat, one without the targeted exotic thistle (Louda 1999). The weevil also interferes with native floral insects dependent on native thistles (Louda \& Arnett 2000). This weevil is a specialist on thistles, so this case highlights the fact that a "narrowly specific host range" is relative to the species composition of the recipient region. The case also suggests the need to add insect population response under various conditions in assessments of ecological risk ( Louda et al. 2003a; 2003b).

Callaway and colleagues (1999) reported that feeding by two specialized tephritid flies (Urophora affinis, $U$. quadrifaciata) introduced against exotic knapweeds (Centaurea maculosa, C. diffusa) indirectly facilitates knapweed growth. Furthermore, Pearson and colleagues (2000) found that when the flies failed to control knapweed, the abundant fly larvae subsidized populations of deer mice (Peromyscus maniculatus), a generalist predator, and mouse populations increased two- to three-fold. As a result, other small mammals have declined, and the native plant community has been altered. This case highlights the need for evidence of a high probability of control, prior to release of putative biocontrol agents. It also illustrates the complexity of outcomes possible with the insertion of exotic species into new communities. Evaluation of such outcomes is not a part of contemporary ecological risk assessment.

Henneman and Memmott (2001) found that insects released as biological control agents in agroecosystems at low elevations on Kauai, Hawaii, have penetrated the high-elevation native forest to the point that an unexpected $83 \%$ of the parasitoids reared from native caterpillars are biocontrol agents. This case highlights the probability of dispersal away from the targeted areas into adjacent natural communities. It also illustrates the potential consequences for the community foodweb of introduced exotic species.

Louda and O'Brien (2002) reported large nontarget effects of Larinus planus on the sparse native Cirsium undulatum var. tracyi in Colorado. This Eurasian weevil was tested in Europe, first observed as an adventive in a biological control test field in the northeastern United States (White 1972), and released officially in Colorado as a biocontrol agent against $C$. arvense (Canada thistle). Release in Colorado occurred even after contemporary host-specificity tests showed that native species were acceptable, but not preferred, hosts (McClay 1990). Unfortunately, however, seed destruction by L. planus is greater on the native species than on the targeted weed. This case illustrates three key points: a discrepancy between predicted host use, based on host-preference tests, and observed host use in the field; the dangers of redistribution of potential "natural enemies" between ecosystems; and shortcomings in the oversight process for movement of "beneficial" exotic species within the country.
In sum, these data augment the cases listed by Hoddle (2004) and document both unexpected interactions and unpredicted intensities of interaction with native species by insects used as biological control agents. Much of the recent evidence emerged serendipitously in the midst of basic ecological studies. Thus, given the general lack of follow-up monitoring in biological control and the serendipity of much of the quantitative data on nontarget effects, the evidence now available may represent only the tip of the iceberg. The current state of knowledge argues for more studies and increased caution in deliberate introductions of exotic species.

\section{Reasons for Caution and Better Development of Risk Assessment}

The issue is not whether biological control is an option in invasive species management. Given the evidence on the unexpected range and magnitude of nontarget effects, the real question is when biocontrol is likely to be both effective and environmentally safe. Long-standing arguments underlying advocacy of classical biological control efforts, reiterated by Hoddle, are (1) economic and environmental benefits, (2) rarity of nontarget effects by specialist insects, (3) regulatory "safety net," and (4) value to conservation. Each of these points has counterpoints that merit repetition, to increase awareness of the questions underlying the assertions and to stimulate further science-based dialogue to resolve the real issues.

First, we concur that biocontrol can be beneficial, when it works. The key phrase, however, is when it works. The probability of control, and thus the likelihood of benefit, is not evaluated quantitatively in pre-release studies. Yet ineffective releases do nothing about the pest and have multiple ecological risks. Hoddle claims that "science-based biological control programs are deliberate and carefully orchestrated ...." Usually, however, as many relatively specific biocontrol agents as can be identified are released in hopes that one will limit the targeted pest, without assessment of the likely outcome or even probability of unwanted interactions among agents (McEvoy \& Coombs 1999, 2000). Moreover, the statistics on success are not encouraging. Based on quantitative criteria, only $20 \%$ of weed-control projects (Williamson \& Fitter 1996) and 3\% of insect-control projects (Lynch \& Thomas 2000) exhibit successful control. Lack of control not only entails unnecessary costs, it can lead to new problems (e.g., Pearson et al. 2000). It also leaves the $34-50 \%$ of the exotic insects that become established in the new environment, without controlling their targeted pest (Greathead \& Greathead 1992). More precise economic analyses, and more accurate representations of the likelihood of success are needed to put the potential ecological costs into a more realistic perspective. 
Second, although use of specialist insects reduces the chance of direct nontarget use (Pemberton 2000), it is not foolproof (Louda et al. 2003b). Hoddle argues that "Natural enemies that exhibit high levels of host and habitat fidelity ensure strong links and maximal impact on the target species, while ensuring weak links and minimal impacts to nontarget species." The problem, of course, is defining "high" in this context. The cases above, and others (Louda et al. 2003b), show that nontarget effects can be imposed by relative "specialists," species whose diet is limited to a set of closely related hosts. Furthermore, most insects released against insect pests do not narrowly specialize; $62 \%$ of parasitoids released are polyphagous (Stiling 1990). At least $23.6 \%$ of the 313 parasitoids released against insect pests in the United States attack nontarget species (Hawkins \& Marino 1997). Also, despite claims to the contrary (Hoddle), host-range expansion by specialized natural enemies occurs: at least 20 cases have been identified (Secord \& Kareiva 1996). Further, nontarget effects are not as rare as suggested; direct, indirect, and cascading effects have been reported (above). Together, these results undermine confidence in relative specialization and host preference as completely adequate criteria for estimation of ecological risks.

Third, although the strict regulatory oversight legislation enacted by New Zealand and Australia provide models for other countries, this safety net is not universal. Voluntary codes are just that, voluntary. Regulators are under political pressure to minimize oversight and are under financial constraints that have a comparable effect. Expediency can overwhelm good intention. Finally, once an exotic species is established, few if any countries have comprehensive, science-based guidelines for internal movement of "beneficial" insect enemies between regions and ecosystems. In sum, we are not persuaded that voluntary restraints and current regulatory oversight protect sensitive natural resources of conservation value in most countries.

Fourth, evidence now suggests that biocontrol may not be as risk-free an option for conservation and restoration as is assumed. We still do not know enough to predict the ecological outcomes of new biological interactions, including deliberate introduction of exotic species. Evaluation procedures in biological control, which rely heavily on host-specificity tests, are not designed to quantitatively predict population impacts on either targeted or nontargeted species or to quantitatively predict alternative outcomes in complex assemblages of species. Why is this important? The magnitude of potential benefits and costs are not well quantified prior to introduction, so trade-off analyses are much more hypothetical than generally thought. This realization is crucial in conservation contexts, where the overarching mandate is to protect native species. Increasing caution, ever-increasing scientific rigor, and a careful reexamination of the assumptions underlying current protocols are needed to improve the prediction of ecological dynamics and outcomes among newly associated species in new environments. Advising increased caution in the application of biocontrol is not to advocate a do-nothing policy. Mechanical and localized chemical control methods exist and, although they take time and resources, may represent less harmful containment strategies in the long run than introducing self-replicating, self-dispersing, irretrievable biological "natural enemies" with unexpected ecological side effects.

\section{Conclusion}

Biological control is a potential tool in the fight to control invasive exotic species, but it is clearly a double-edged sword. Given the evidence available, we think the focus now should be on when biocontrol will be both effective and ecologically safe. Although Hoddle acknowledges some of the problems, his basic message could be construed as a generalized recommendation for biocontrol in sensitive natural areas. Yet it is important to avoid using classical biocontrol as the reflexive response to invasive species (Michaud 2002). The evidence now contradicts the simplistic, optimistic perspective that the practice of introducing and redistributing exotic species is so carefully targeted, so adequately analyzed, and so well regulated that-done according to current protocols - it poses no credible ecological risk to natural systems. We disagree and conclude that better quantification of both likely benefits and possible ecological costs are required before applying the dramatic and potentially risky strategy of introducing exotic spcies against exotic species in a conservation context.

\section{Acknowledgments}

We appreciate comments on the manuscript from $\mathrm{K}$. H. Keeler, A. Joern, T. E. Miller, T. A. Rand, F. L. Russell, and L. M. Young. Support for work on thistles was provided by National Science Foundation grants (DEB9221065, DEB96-15299), a U.S. Department of Agriculture National Research Initiative grant (2001-35320-09882), The Nature Conservancy's Rodney Johnson and Katharine Ordway Stewardship Endowments, and the University of Nebraska Research Council.

\section{Literature Cited}

Callaway, R. M., T. H. DeLuca, W. M. Belliveau. 1999. Biological-control herbivores may increase competitive ability of the noxious weed Centaurea maculosa. Ecology 80 : 1196-1201. 
Greathead, D. J., A. H. Greathead. 1992. Biological control of insect pests by insect parasitoids and predators: the BIOCAT database. Biocontrol News and Information 13: 61-68.

Hawkins, B. A., P. C. Marino. 1997. The colonization of native phytophagous insects in North America by exotic parasitoids. Oecologia ( Berlin ) 112 : 566-571.

Henneman, M. L., J. Memmott. 2001. Infiltration of a Hawaiian community by introduced biological control agents. Science 293 : 1314-1316.

Hoddle, M. S. 2004. Restoring balance: using exotic species to control invasive exotic species. Conservation Biology 18 : 38-49.

Howarth, F. G. 1991. Environmental impacts of classical biological control. Annual Review of Entomology 36 : 485-509.

Johnson, D. M., P. D. Stiling. 1996. Host specificity of Cactoblastis cactorum (Lepidoptera: Pyralidae), an exotic Opuntiafeeding moth, in Florida. Environmental Entomology 25 : 743-748.

Louda, S. M. 1999. Negative ecological effects of the musk thistle biocontrol agent, Rhinocyllus conicus Fröl. Pages 215-243 in P. A. Follet J. J. Duan, editors. Nontarget effects of biological control. Kluwer Academic Publishers, Boston .

Louda, S. M., A. E. Arnett. 2000. Predicting non-target ecological effects of biological control agents: evidence from Rhinocyllus conicus. Pages 551-567 in N. R. Spencer, editor. Proceedings of the 10th International symposium on the biological control of weeds. Montana State University Press, Bozeman, MT.

Louda, S. M., C. W. O’Brien. 2002. Unexpected ecological effects of distributing the exotic weevil, Larinus planus (F.), for the biological control of Canada thistle. Conservation Biology 16 : 717-727.

Louda, S. M., M. A. Potvin. 1995. Effect of inflorescence-feeding insects in the demography and lifetime fitness of a native plant. Ecology $76: 229-245$.

Louda, S. M., D. Kendall, J. Connor, D. Simberloff. 1997. Ecological effects of an insect introduced for the biological control of weeds. Science 277 : 1088-1090.

Louda, S. M., D. Simberloff, G. Boettner, J. Connor, D. Kendall, A. E. Arnett. 1998. Insights from data on the nontarget effects of the flowerhead weevil. Biocontrol News and Information $26: 70 \mathrm{~N}-71 \mathrm{~N}$.

Louda, S. M., A. E. Arnett, T. A. Rand, F. L. Russell. 2003a. Invasiveness of some biological control insects challenges adequacy of ecological risk assessment and regulation. Conservation Biology 17 : 1-11.

Louda, S. M., R. W. Pemberton, M. T. Johnson, P. A. Follett. 2003b. Nontarget effects: the Achilles' heel of biological control? Retrospective analyses to reduce risk associated with biocontrol introductions. Annual Review of Entomology 48 : 365-396.[PubMed link]

Lynch, L. D., M. B. Thomas. 2000. Nontarget effects in the biological control of insects with insects, nematodes and microbial agents: the evidence. Biocontrol News and Information 21 : 117-130.

McClay, A. S. 1990. The potential of Larinus planus (Coleoptera: Curculionidae), an accidentally-introduced insect in North America, for biological control of Cirsium arvense. Pages
173-179 in E. S. Delfosse, editor. Proceedings of the 7th international symposium on the biological control of weeds. Instituto Sperimentale per la Patologia Vegetale, Rome, Italy.

McEvoy, P. B., E. M. Coombs. 1999. A parsimonious approach to biological control of plant invaders. Ecological Applications 9 : 387-401.

McEvoy, P. B., E. M. Coombs. 2000. Why things bite back: unintended consequences of biological control of weeds. Pages 167-194 in P. A. Follett, J. J. Duan, editors. Nontarget effects of biological control. Kluwer Academic Publishers, Boston .

Menge, B. A. 1997. Detection of direct versus indirect effects: were experiments long enough? The American Naturalist 149 : 801-823.

Michaud, J. P. 2002. Classical biological control: a critical review of recent programs against citrus pests in Florida. Annals of the Entomological Society of America 94 : 531-540.

Paine, R. T. 1992. Food web analysis through field measurement of per capita interaction strength. Nature ( London ) $355: 73-75$.

Pearson, D. E., K. S. McKelvey, L. F. Ruggiero. 2000. Non-target effects of an introduced biological control agent on deer mouse ecology. Oecologia ( Berlin ) 122 : 121-128.

Pemberton, R. W. 2000. Predictable risk to native plants in weed biological control. Oecologia ( Berlin ) 125 : 489-494.

Secord, D., P. Kareiva. 1996. Perils and pitfalls in the host specificity paradigm. BioScience $46: 448-453$.

Simberloff, D., P. Stiling. 1996. How risky is biological control? Ecology 77 : 1965-1974.

Stiling, P. 1990. Calculating establishment rates of parasites in classical biological control. American Entomologist 36 : 225-230.

Stiling, P. 2002. Potential non-target effects of a biological control agent, prickly pear moth, Cactoblastis cactorum (Berg) (Lepidoptera: Pyralidae), in North America. Biological Invasions $4: 273-281$.

Stiling, P., A. Rossi, D. Gordon. 2000. The difficulties of single factor thinking in restoration: replanting a rare cactus in the Florida Keys. Biological Conservation 94 : 327-333.

Strauss, S. Y. 1991. Indirect effects in community ecology: their definition, study and importance. Trends in Ecology \& Evolution 6 : 206-210.

Wajnberg, E., J. K. Scott, P. C. Quimby. 2001. Evaluating indirect ecological effects of biological control. CABI Publishing, Wallingford, United Kingdom .

White, J. C. 1972. A European weevil, Larinus carlinae Oliver, collected in Maryland. Cooperative Economic Insect Report $22: 418$.

Williamson, M., A. Fitter. 1996. The varying success of invaders. Ecology 77 : 1661-1666.

Wooton, J. T. 1994. The nature and consequences of indirect effects in ecological communities. Annual Review of Ecology and Systematics $25: 443-466$. 